\title{
Knowledge on Tobacco Control Campaigns and Recommendations for Reduction of Tobacco Use: A Cross- Sectional Study Recommendations for Reduction of Tobacco Use
}

\author{
Tütün Kontrolü Kampanyaları Bilgi Durumları ve Tütün Kullanımının Azaltılması \\ Önerileri: Kesitsel Çalışma Tütün Kullanımı Azaltılması İçin Öneriler
}

\author{
Sebahat Gücük*1, İbrahim Levent Yıldırmaz ${ }^{2}$
}

\begin{abstract}
Introduction: It is the determination of information about the tobacco control campaigns in our country registered by the Family Health Center. Method: A questionnaire of 38 questions was applied to the participants. In the first part of the questionnaire, socio-demographic characteristics and smoking status, in the second part, the information about their knowledge of the "Law on the Prevention and Control of Harmful Effects of Tobacco Products" and their opinions on the relevant campaigns were examined. Findings: The average age of the participants was $38.4 \pm 13.0$ years. Of the participants, $228(53.1 \%)$ had been to a place where people smoked. A total of 151 (35.2\%) of the participants were smokers and 164 of them $(38.2 \%)$ had someone in their household who smoked. Non-smoker females were more frequently exposed to indoor smoking than non-smoker males $(\mathrm{p}=0.01)$. A total of 397 participants $(92.5 \%)$ expressed a desire for a more intense introduction of tobacco control practices in educational activities for young people, while 400 of them (93.2\%) suggested implementation of mass educational programs for women who undertake an important role in children's education. Conclusion: Smoking is quite common in our geographical region. Based on the current results, we, as family physicians, can provide support for families and their immediate surroundings about existing laws on tobacco and tobacco products as well as how not to ever start smoking or stop it if it has already started. And, we can follow-up on that to create positive effects on individuals themselves and their surroundings by increasing their awareness of the current functioning of the system.
\end{abstract}

Key words: Smoke, primary care, cross sectional

\section{ÖZET}

Amaç: Aile Sağlı̆̆ı Merkezimize kayıtlı bulunan kişilerin, ülkemizdeki tütün kontrol kampanyaları hakkındaki bilgi durumlarının belirlenmesidir. Yöntem: Katılımcılara 38 soruluk bir anket uygulanmıştır. Anketin ilk bölümünde sosyo-demografik özellikleri ve sigara içme durumları, ikinci bölümünde "Tütün Ürünlerinin Zararlarının Önlenmesi ve Kontrolü Hakkında Kanun" ile ilgili bilgi durumları ve yapılan kampanyalara yönelik görüşleri sorgulanmıştır. Bulgular: Katılımcıların yaş ortalaması 38,4 $\pm 13,0$ yıl olarak tespit edilmiştir. Geçmiş yaşamlarında sigara içilen ortamlarda bulunan kişi sayısı $228(\% 53,1)$ idi. Katılımcıların \%35,2'si (n=151) sigara içen grubunda bulunmaktadır. Evinde aktif olarak sigara içilen kişi sayısı $164(\% 38,2)$ idi. Sigara kullanmayan kadınlar sigara kullanmayan erkelere oranla, ev içi maruziyete daha sık kaldığı saptanmıştır $(\mathrm{p}<0,01)$. Katılımcıların \%92,5'i $(\mathrm{n}=397)$, tütün kontrol uygulamalarının gençlere yönelik verilecek eğitimlerde daha yoğun anlatılmasını isterken, \%93,2'si (n=400) çocukların eğitiminde önemli rol üstlenen kadınlara yönelik yaygın eğitim programlarının düzenlenmesi önerisinde bulunmuşlardır. Sonuç: Bölgemizde, sigara kullanımı oldukça sık görülmektedir. Önerilerin çok büyük bölümü aslında mevcut kanunlarımızın içinde bulunmakta ve geniş kitlelere ulaşılması yönünde çalışılmaktadır. Bu mevcut sonuçlarla; aile hekimleri olarak aileye ve yakın çevresine tütün ve tütün ürünleri hakkındaki mevcut kanunlar, sigaraya başlamama ve başlanmışsa bırakma konusunda verilecek destek ve takiple, kişilerin mevcut işleyiş hakkındaki farkındalıklarının artırılması sağlanarak, hem kendilerinde, hem de çevrelerinde olumlu etkiler oluşturulmasında yardımcı olunabileceği düşünülmektedir.

Anahtar kelimeler: Sigara, birinci basamak, kesitsel

Received / Geliş tarihi: 11.06.2018, Accepted / Kabul tarihi: 20.09.2018

${ }^{1}$ Abant İzzet Baysal Üniversitesi Tıp Fakültesi, Aile Hekimliği Anabilim Dalı, Bolu

2 İzzet Baysal Aile Sağlığı Merkezi, Aile Hekimliği Uzmanı, Bolu

*Address for Correspondence / Yazışma Adresi: Sebahat Gücük, Abant İzzet Baysal Üniversitesi Tıp Fakültesi, Aile Hekimliği Anabilim Dalı, Bolu -

TÜRKIYE, E-mail: sebahatgu@yahoo.com

Gücük S, Yıldırmaz İL. Tütün Kontrolü Kampanyaları Bilgi Durumları ve Tütün Kullanımının Azaltılması Önerileri: Kesitsel Çalışma Tütün Kullanımı Azaltılması İçin Öneriler. TJFMPC, 2019;13(1): 34-41.

DOI: $10.21763 /$ tjfmpc.528009 


\section{GíRiş}

Dünya Sağlık Örgütü (DSÖ) verilerine göre, halen sigara kullanımına bağlı sağlık sorunları en önemli önlenebilir mortalite ve morbidite nedenlerinden biridir. ${ }^{1}$ DSÖ’nün, 2012 yılında yayınlamış olduğu 15 yaş üzeri bireylerin tütün ürünü kullanımı verilerine göre; Ülkemizde erkeklerin \%42,7'si, kadınların \%13,5'i sigara içmektedir. Aynı oranlar sırasıyla, Çin Halk Cumhuriyeti için \%49 ve \%2, Amerika Birleşik Devletleri için \%21 ve \%16,3 olarak saptanmıştır. ${ }^{2}$ Aynı yıl Türkiye İstatistik Kurumu verilerinde ise sigara içme sıklığ $25-34$ yaş grubunda \%34,9, 35-44 yaş grubunda ise \%36,2 'dir. ${ }^{3}$ Sigara, başta kanser, akciğer, kalp rahatsızlıkları gibi çok sayıda sağlık sorununa yol açmaktadır. ${ }^{4} 2020$ y1lında tüm dünyada 10 milyon, yüzyılımızda ise bir milyar insanın sigara yüzünden erken yaşlarda öleceği beklenmektedir. ${ }^{5,6}$ Türkiye'de 1990'lı yılardan itibaren tütün kullanımı konusunda yasal düzenlemeler gündeme gelmiş ve ilk kez 1996 yılında "Tütün Mamullerinin Zararlarının Önlenmesine Dair Kanun” (No:4207) ile yürürlüğe girmiştir. Bu yasa ile, ilk kez tütün ürünlerinin her türlü reklam ve tanıtımı yasaklanmış ve tütün ürünü tüketimi konusunda kısıtlamalar getirilmiştir. ${ }^{7}$ Dünya çapında tütün kullanımının giderek artması ve insan sağlığına olan tehdidi, tütün şirketlerinin özellikle gelişmekte olan ülkelerde pazar genişletme çabalarına karşı geliştirilen, tütün kontrolüne yönelik ilk uluslararası anlaşma olan "Tütün Kontrol Çerçeve Sözleşmesi” 25 Kasım 2004 tarihinde, Türkiye Büyük Millet Meclisi tarafından kabul edilerek, 30 Kasım 2004 tarihli, 25656 sayılı Resmi Gazete'de 5261 kanun numarası ile yayımlanmıştır. Kanunlaşan bu sözleşme çerçevesinde, yapılacak çalışmaların planlanması ve sigara tüketiminin kontrol altına alınması amaciyla 2008-2012 yıllarını kapsayacak şekilde "Ulusal Tütün Kontrol Programı ve Eylem Planı" hazırlanmıştır. ${ }^{8}$ Kontrol Programı ve Eylem Planı Daha sonra yenilenerek 2015-2018 yıllarını kapsayacak şekilde yeniden yayınlanmıştır.

Tütün kontrolü çalışmalarında başarılı ülkelerde tütün kullanım sıklığı bilgileri ile ilgili düzenli çalışmalar yapılmakta ve sigara içme durumları takip edilmektedir. ${ }^{10}$ "Küresel Yetişkin Sigara Araştırması" sonuçlarına göre, Türkiye'de sigara kullanma durumunun, toplum genelinde erkeklerde 6,5 puan, kadınlarda ise 2,1 puan düştüğü, kişi başına sigara tüketiminin de azalma eğiliminde olduğu saptanmıştır. ${ }^{11}$ Sigara içme sıklığı ve nedenleri ile ilgili yapılan çalışmaların, sigara içimini azaltmaya ya da önlemeye yönelik uygun yöntemlerin belirlenmesi veya girişimlerin etkinliğinin değerlendirilmesi için önemli görülmektedir. ${ }^{12}$
Birincil koruma ile özellikle çevresel faktörler gibi birçok nedenden kaynaklanan hastalıklar önlenebilmektedir. Sigara içiminin önlenmesi, kullananların sigarayı bırakmaları birçok hastalığ1 önlemede etkin olacak birincil koruma yöntemlerinden biridir. Sigara içimi gibi önlenebilir sağlık sorununun çözümünde, aile hekimliği disiplini ve uygulamasına önemli görevler düşmektedir. ${ }^{13}$ Sigara içiminin önlenmesinde, sigara içenlerin saptanmasında, değerlendirilmesinde ve tedavisinde birinci basamak anahtar rol oynamaktadır. ${ }^{14}$ Disiplinimizin sahip olduğu ilkeler, nikotin bağımlılığına yaklaşımda kullanılan bilimsel yöntemleri destekleyici niteliktedir ve buda hekimlerimizin görevlerini kolaylaştırmaktadır. ${ }^{13}$

Çalışmamız, aile sağlığı merkezimize başvuran hastaların tütün kontrol kampanyaları hakkındaki bilgi durumları, tütün ve tütün ürünleri kullanımına başlanmaması ve başlanmışsa kullanımının bırakılması için olası önerilerinin belirlenmesi amacıyla gerçekleştirilmiştir.

\section{YÖNTEM}

Araştırmamız, Aralık 2017 - Mayıs 2018 tarihleri arasında, Bolu merkez bölgesindeki tek bir aile sağlığı merkezine (ASM) herhangi bir nedenle başvuran ve çalışmamıza katılmayı kabul eden 429 gönüllü katılımcının, aile hekimliği uzmanı tarafından yüz yüze görüşmesi ile gerçekleştirilen, kesitsel ve analitik bir çalışmadır. Çalışma gerçekleştirildiği sırada, ASM'nin18 yaş ve üzeri kayıtlı toplam nüfusu 2657 kişiydi ve bunların 1382'si kadın, 1275'i ise erkekti. Belirlenen çalışma süresinde 429 kişi $(\% 16,1)$ ile çalışmamız tamamlanmıştır. Çalışma grubunu 18 yaş üzerinde ve ASM'ye kayitll, herhangi psikiyatrik bir rahatsızlığı olmayan, anket cevaplandırılmasında engel bir durumu olmayan kişiler oluşturmuştur. Çalışmaya katılan bireylere, çalışma hakkında bilgi verildikten sonra sözlü onamları alınmıștır. Tüm katılımcılara 38 soruluk bir anket uygulanmıştır. Anketin ilk bölümünde sosyo-demografik özellikleri ve sigara içme durumları, ikinci bölümünde "Tütün Ürünlerinin Zararlarının Önlenmesi ve Kontrolü Hakkında Kanun" ile ilgili bilgi durumları ve yapılan kampanyalara yönelik görüşleri sorgulanmıştır. Tütün kullanımına başlamama ve başlanmışsa bırakılmasına yönelik toplumsal katılımın sağlanabilmesi için önerilerini yazmaları istenmiş, alınan önerileri kendi aralarında kategorize edilerek değerlendirilmiştir.

Geçmişte sigara içilen yer ve şu anda sigara içiliyorsa, sigara içilen yer sorusuna sigara içmek için sıklıkla kullanılan mekânın belirtilmesi istenmiştir. Çalışmamız, sigara, sarma sigara kullananların tümü dâhil edilerek planlanmıştır. Sigara içme durumunu, sigara içmeyen: Toplam 100 
sigaradan daha az sigara içen. Sigarayı bırakmış: Geçmişte içtiği sigara sayısı 100 'ü geçmiş ve sonrasında bırakmış olanlar. Sigara içen: Düzenli veya düzensiz kullanımına bakılmaksızın, toplam içtiği sigara sayısı yüzü aşmış olanlar sigara içenler olarak gruplandırılmıştır. Türkiye'de, toplumda sigara içme sıklığını belirlemeye yönelik çalışmaların daha çok bölgesel yapıldığı ve sigara içme tanımının ortak olmadığı görülmektedir. ${ }^{15}$

Sigara kullanım yılı, günlük içilen adet ve şu ana kadar içilen yıllar alınarak paket /yıl olarak hesaplanmıştır. Sigara kullananlara Fagerström nikotin bağımlılık testi uygulanmıştır.

Çalışmamız için, Bolu Abant İzzet Baysal Üniversitesi Klinik Araştırmalar Etik Kurulundan gerekli etik onay alınmıştır.

\section{Fagerström Nikotin Bağımlılık Testi (FNBT)}

Altı adet sorudan oluşmaktadır. FNBT'den alınabilecek en küçük puan 0 , en büyük puan 10 olup puan yükseldikçe bağımlılık düzeyi artmaktadır. Kişilerin, FNBT'den aldığı puana göre bağımlılık derecesi; çok düşük (0-2 puan), düşük (3-4 puan), orta (5-6 puan), yüksek (7-8 puan) ve çok yüksek (910 puan) olarak sinıflandırılmaktadır. ${ }^{16}$

\section{İstatistiksel Analiz}

Veriler, IBM SPSS (Statistical Program for Social Sciences, V.23) programı kullanılarak, nicel veriler standart sapma, en küçük -en büyük değer, nitel veriler ise yüzde olarak sunularak ki kare, çok gözlü ki-kare, Kruskal-Wallis, Mann-Whitney U ilişki testleri ile \%95 güven aralığında, analiz edilmiştir.

\section{BULGULAR}

Katılımcıların yaş ortalaması 38,4 $\pm 13,0$ (min. $=18$ max. $=73)$ yıl idi. Katılımcıların \%53,8'i (n=231) erkek, \%46,2's1 (n=198) kadın ve \%55'i (n=236) evli olarak saptanmıştır. Vakaların \% 53,1'i (n:228) geçmiş yaşantılarında sigara içilen ortamda bulunmuştur. Katılımcıların \%35,2'si (n:151) halen düzenli olarak her gün sigara içtiği tespit edilmiştir. Sigara içen bu vakalar, FNBT'den ortalama $6,0 \pm 2,2$ $(\min =2 ; \max .=10)$ puan almışlardır. Sigara içenlerin \%30,5'i (n=46) birden çok kez sigarayı bırakmayı denediğini belirtmiştir. Sigara içenlerin \%68,2'sinin $(\mathrm{n}=103)$ paket/y1l değeri 20'nin üzerinde iken, \%26,6's1 (n=190) 20 adet/gün ve üzeri sigara içtiği tespit edilmiştir. Çalışmaya dâhil edilen vakaların $\% 38$,2'sinin ( $\mathrm{n}=164)$ evinde aktif olarak sigara içilmekteydi. $\mathrm{Bu}$ vakaların \%16,5'u $(\mathrm{n}=71)$ evin içinde sigara içilmeyen özel bir yer olmadığını sigara içenlerin herhangi bir yerde içebildiğini belirtmiştir. Sigara kullanmayan kadınlar, sigara kullanmayan erkeklere oranla ev içi maruziyete daha sik kalmaktadır $(\mathrm{p}<0,01)$. Sigara kullanma ile medeni durum, eğitim durumu arasında anlamlı bir ilişki saptanmamıştır (sırasıyla $p=0,41$ ve $p=0,52$ ). Sigara kullanma durumu ile ilgili değişkenler Tablo 1'de gösterilmiştir.

Sigara içenlere, “’Tütün Ürünlerinin Zararlarının Önlenmesi ve Kontrolü Hakkında Kanun”ile ilgili ilk düşünceleri sorulduğunda, \%86,8'i (n=131) olumlu olarak karşıladıklarını belirtmişlerdir. "Tütün Ürünlerinin Zararlarının Önlenmesi ve Kontrolü Hakkında Kanun” hakkında duydukları bilgiyi nereden öğrendikleri sorulduğunda, \%39,6'i (n=170) yalnızca medya, $\% 38,7$ 'si $(n=166)$ birden fazla kaynaktan duymuş olabileceğini,\%19,8'i (n=85) sağlık kurumları olarak cevap vermişlerdir. "Sigara ile ilgili uyarıların sizdeki etkisi" nedir diye sorulduğunda, \%20,3'ü $(n=87)$ hiçbir şekilde etkilemediğini, \%37,5'i de $(n=161)$ etkilendiğini ve içmediğini fakat bu konuda etrafındaki insanlarda bir değişiklik oluşturamadığını belirtmiştir. Yasa ile ilgili yapılan uyarıların kişiler üzerinde etkililiği konusundaki sonuçlar Tablo 2'de gösterilmiştir. "Kapalı alanlarda ve işyerlerinde sigara içilmesini yasaklayan bu kanun ile ilgili bir şey duydunuz mu?" sorusuna $\% 35$ 'i $(n=151)$ yeterince bilgim var cevabın1 vermişlerdir. \% 53,3'ü $(\mathrm{n}=247)$ bu uyarılar beni rahatsız ediyor derken, $\% 40,3$ 'ü $(n=173)$ en az bir kere uyarı yazılarına rağmen kapalı mekânda sigara içtiğini belirtmiştiri. Bütün bunlara rağmen, \%65,7 'si ( $\mathrm{n}=282$ ) yasanın uygulanabilmesini tamamen desteklediklerini belirtmişlerdir

Katılımcıların \%92,5'i (n=397) tütün kontrol uygulamalarının, gençlere yönelik verilecek eğitimlerde daha yoğun anlatılmasını isterken, $\% 93,2$ 'si $(n=400)$ çocukların eğitiminde önemli rol üstlenen kadınlara yönelik yaygın eğitim programlarının düzenlenmesi önerisinde bulunmuşlardır. Katılımcıların \%67,4'ü $(n=289)$, gençlerin örnek alacağı başta öğretmen gibi kişilerin bu konuda daha duyarlı davranmalarını istemişlerdir. Çalışmaya katılan vakaların, sigara kullanımının azaltılmasına yönelik yaklaşımların etkinlikleri konusundaki görüşleri Tablo 3 'de gösterilmiştir.

\section{TARTIŞMA}

Çalışmamızda, ASM'mize kayıtlı 18 yaş üzeri kişilerde, her gün sigara içme oranı \%35,2 olarak bulunmuştur. Türkiye'de, yetişkinlerde tütün kullanımı oldukça yaygın olduğu bulunmuştur. Bu konuda, ulusal düzeydeki ilk çalışma 1988 yılında yapılmış ve 15 ve üzeri yaş grubunda sigara kullanım siklığ $1 \% 44$ olarak bulunmuştur (E: \%62, K: \%24). ${ }^{17}$ 2003 y1lında yapılan "Ulusal Hane Halkı" çalışmasında sıklığın \% 32,1 olduğu bildirilmiştir. ${ }^{18}$ Türkiye İstatistik Kurumu'nun yaptığı araştırmaya 


\begin{tabular}{|c|c|c|c|c|c|c|c|c|c|c|}
\hline & & & \multicolumn{6}{|c|}{ Sigara kullanım durumu } & \multirow{2}{*}{\multicolumn{2}{|c|}{ Toplam }} \\
\hline & & & \multicolumn{2}{|c|}{ İçmiyor } & \multicolumn{2}{|c|}{ İçiyor } & \multicolumn{2}{|c|}{ Bırakmış } & & \\
\hline & & & $\mathrm{n}$ & $\%$ & $\mathrm{n}$ & $\%$ & $\mathrm{n}$ & $\%$ & $\mathrm{n}$ & $\%$ \\
\hline \multirow{4}{*}{ Kadın } & \multirow{2}{*}{$\begin{array}{l}\text { Eğitim } \\
\text { durumu }\end{array}$} & İlköğretim veya daha az & 87 & 74,4 & 30 & 25,6 & 0 & 0 & 117 & 100 \\
\hline & & Lise veya üzeri eğitimli & 70 & 86,4 & 11 & 13,6 & 0 & 0 & 81 & 100 \\
\hline & \multirow[t]{2}{*}{ Yaş } & $18-35$ yas & 69 & 79,3 & 18 & 20,7 & 0 & 0 & 87 & 100 \\
\hline & & $\geq 35$ yaş & 87 & 79,1 & 23 & 20,9 & 0 & 0 & 100 & 100 \\
\hline \multirow{4}{*}{ Erkek } & \multirow{2}{*}{$\begin{array}{l}\text { Eğitim } \\
\text { durumu }\end{array}$} & İlköğretim veya daha az & 13 & 22,8 & 43 & 75,4 & 1 & 1,8 & 57 & 100 \\
\hline & & Lise veya üzeri eğitimli & 67 & 38,5 & 67 & 38,5 & 40 & 23 & 174 & 100 \\
\hline & \multirow[t]{2}{*}{ Yaş } & $18-35$ yaş & 42 & 52,5 & 20 & 25 & 18 & 22,5 & 80 & 100 \\
\hline & & $\geq 35$ yas & 38 & 25,2 & 90 & 59,6 & 23 & 15,2 & 151 & 100 \\
\hline
\end{tabular}

Tablo 2. Çalışmaya katılan vakaların sigara kullanımının azaltılmasına yönelik yaklaşımların etkinlikleri konusundaki görüşleri

\begin{tabular}{|l|l|l|l|l|}
\hline & Etkili & Etkisiz \\
\hline & n & \% & n & \% \\
\hline Kapalı yerlerde sigara içme yasağı & 391 & 91,1 & 38 & 8,9 \\
\hline Paketlerdeki uyarı yazıları & 194 & 45,2 & 235 & 54,8 \\
\hline Sağlık personelinin bilgilendirmeleri & 314 & 73,2 & 115 & 26,8 \\
\hline Televizyondaki kamu spotları & 210 & 49,0 & 219 & 51,0 \\
\hline Radyodaki yayınlar & 202 & 47,1 & 227 & 52,9 \\
\hline Basılı yayındaki haberler & 209 & 48,7 & 220 & 51,3 \\
\hline
\end{tabular}

\begin{tabular}{|l|l|l|}
\hline \multicolumn{2}{|l|}{ Tablo 3. Katılımcılarımızın sigaraya başlamama ve başlanmıssa bırakma için önerileri } \\
\hline & $\mathbf{n}$ & $\%$ \\
\hline Kadınlara yönelik yaygın eğitim programlarının düzenlenmesi & 400 & 93,2 \\
\hline $\begin{array}{l}\text { Tütün kontrol uygulamaları konusunda gençlere yönelik } \\
\text { verilecek eğitimler }\end{array}$ & 397 & 92,7 \\
\hline $\begin{array}{l}\text { Bağımlılık için alabilecekleri tedavinin kolay ulaşabilmek için } \\
\text { birinci basamakta yapılabilmesini }\end{array}$ & 398 & 86,0 \\
\hline $\begin{array}{l}\text { Tütün ve tütün ürünlerinin satı̧̧ fiyatının almakta zorlanılacak } \\
\text { kadar yükseltilmesi }\end{array}$ & 334 & 85,1 \\
\hline $\begin{array}{l}\text { Öğretmen gibi rol model olabilecek kişilerin konuya daha duyarlı } \\
\text { olması }\end{array}$ & 289 & 67,4 \\
\hline Kaçak olan satışların önlenmesi & 303 & 65,4 \\
\hline
\end{tabular}


göre, ülkemizde 15 yaş üzeri nüfusta sıklık \%31.2 (erkek \%47.9, kadın \%15.2) olarak bildirilmiştir. ${ }^{11}$ Şengezer ve arkadaşlarının çalışmalarında \%29 iken ${ }^{19}$, Kosku ve arkadaşlarının çalışmasında \%35.3 bulunmuştur. ${ }^{20}$ Çalışmamızda verilen oranların 18 yaş altı sigara içenler dâhil edilerek düşünüldüğünde artacağ1 tahmin edilmektedir. $\mathrm{Bu}$ sigara içme oranları yüksekliği, çalışma yapıldığ öncesinde ilimizdeki sigara bırakma polikliniği sayılarımızın azlığından ve tedavi verilen hastaların kontrol takiplerinin donanım ve çalışan eksikliğinden dolayı yeteri şekilde yapılamıyor olmasından kaynaklanabileceği düşünülmektedir.

Çalışmamızda, vakaların \%38,2'sinin evinde herhangi bir yerde sigara içildiği saptanmıştır. Bu durum, özellikle sigara içmeyen bireylerin bağımlılık geliştirmeleri için risk teşkil etmektedir. Daha önce yapılan bazı çalışmalarda ev halkı ve yakın arkadaşlarında sigara içenlerin oranının yüksek olmasının sigaraya başlama yaşı ve kullanmalarında önemli etken olduğu saptanmıştır.19,21-24 Kutlu ve Nehir'in yaptıkları çalışmalarında, sigara içen katılımcıların çoğunun aile ve yakın çevresinde sigara içildiği saptanmıştır. ${ }^{25,26}$ Bizim çalışmamızda da benzer şekilde, geçmişte sigara içilen ortamda bulunmuş olanlarda yâda aktif sigara içilen ortamda yaşayanlarda daha fazla sigara içildiği saptanmıştır.

Tütün ürününe başlama, alışma, sürdürme ve bağımlılığın ortaya çıkış süreci her bir birey için farklı ve kişiye özgü olduğu düşünülmektedir. Aile hekimliği, sadece bağımlılıkla değil kişilerle ve onların yaşadıkları ortamlarda oluşan sorunları da dikkate almaktadır. Kişinin tütünle ilgili sağlık inanışları, korkuları, beklentileri ve gereksinimleri merkeze alınmalıdır. Tütün kullanımı, sadece bireyi değil hem ailesini, hem de toplumu çok yakından ilgilendirmektedir. $\mathrm{Bu}$ da, aile hekimine henüz eylem aşamasına geçmemiş bireylerin aile ve yakın çevresini korumak sorumluluğunu da yüklemektedir. Dolayısıyla ergenlik döneminden başlanarak, kişilerin tütün ve tütün ürünleri ile karşılaşmaması için çaba sarf edilmelidir. ${ }^{13}$ Bütün bunlar dikkate alındığında, birinci basamakta özellikle ileride birer anne baba olacak genç yaş grubu olmak üzere, her yaş grubuna sigaraya başlamamaları konusunda destek sağlanmalıdır. Aile hekimleri olarak, kişilerin üzerinde olan etkileri düşünüldüğünde, sigara içmeyi bırakma desteğimizde aile ve yakın arkadaş çevreleriyle de iletişim içinde olmak uygun olacaktır. Bizim çalışmamızda da, kampanyalardan etkilenmediğini ya da etkilendiği halde içmeye devam ettiğini söyleyenlerin oranı yüksekti. Aile hekimlerinin birçok açıdan olduğu gibi kayıtlı nüfusunun sağlık davranışlarını en iyi bilen konumundaki kişi olduğunu düşündüğümüzde, kişilerin anlayabileceği yöntemlerle sigara konusundaki eğitimleri kişiselleştirmesi ve herhangi bir nedenle olan başvurularında bu konuda yapılanların pekiştirilmesi verimliliği artırabilir. Sonuçlarımız, bölgemizdeki bireylerin en çok kadınlara daha sonra gençlere eğitim hizmetinin verilmesinin sigara bağımlılığ1 gelişmesini engelleyeceğini düşündügüünü göstermektedir.

Hükümetler, sigara ve alkol ürünlerinin üzerine yüksek oranda vergi koyarak, bu ürünlerin tüketim eğilimini azaltma çabası içine girmektedirler. Ülkeler bu yolla yüksek vergi geliri elde ederken, sigara ve alkolden kaynaklanan sağlık harcamalarından tasarruf etmek istemektedirler. ${ }^{27}$ Önsüz ve arkadaşlarının çalışmalarında, sigara birakma nedeni olarak gösterilenlerden biride ekonomik nedenler olmuştur. ${ }^{28}$ Çalışmalarda, sigara fiyatlarındaki artışla beraber sigara kullanımının da azaldığ1 gösterilmişse $\mathrm{de}^{29}$,tütün ürünlerinin fiyatlarının arttırılmasının, işsizlerde ve yoksullarda her zaman tütün kullanımını beklendiği kadar azaltan bir politika olmadığının gösterildiği çalışmalar da bulunmaktadır. ${ }^{30-33}$ Katılımcıların büyük çoğunluğu alınmasında zorlanılacak fiyat artışlarının olması yönünde öneride bulunmuşlardı. MPOWER (Monitor Protect Offer Warn Enforce Raise) programının ana öğelerinden birisi sigara üzerinden alınan verginin arttırılması yönündedir. Ancak bu durumun istenmeyen bir başka etkisi, insanların kaçak sigara içmesidir. Piyasada kontrolsüz ve ucuz sigara satışının olması, tütün kullanımının azaltılması mücadelesini yavaşlatmaktadır. Sigara paketi üzerinde bandrolün olmama durumuna bağlı olarak tüketilen sigaraların \%9,1'inin kaçak sigara olduğu ifade edilmektedir. ${ }^{34}$

Yıllık genç, kadın, erkek başvuru sayıları dikkate alındığında, bir hizmetin birinci basamak sağlık kuruluşlarına entegre edilmesi başarıya ulaşma olasılığını artırmaktadır. Sigara mücadelesinde de, birinci basamak sağlık kuruluşları yer alırsa başarı olasılığı yükselecektir.. ${ }^{35}$ Sigara bırakma amaçlı önerilen farmakolojik tedaviler, değişen zamanlarda TC.Sağlık Bakanlığ tarafindan (sigara birakma polikliniklerinde bu konuda verilen eğitimi almış hekimler tarafından reçetelenirse verilebilecek şekilde) ücretsiz desteklenmektedir. Yaklaşık 16 milyon insanın sigara içtiği ülkemizde, yılda dağıtılan ilaç paket sayıları bu rakamlara göre oldukça düşük kalmaktadır. Sadece ücretsiz ilaç dağıtmak, ulaşılan kutu sayısına bakıldığında oldukça ciddi olan bu halk sağlı̆̆ problemini çözmek için uygun bir strateji gibi görünmemektedir. Aile Hekimliği Uzmanlık eğitiminde, sigara bırakma danışmanlık becerisi eğitimleri uygulamalı bir şekilde özenle yapılmaktadır ve uzmanlık eğitimi tamamlandığında, uzmanlarımız sigara birakma konusunda başarılı bir şekilde çalışabilecek donanıma sahip olmaktadır. Buna rağmen, birinci 
basamakta çalışan hekimlerimiz sigara bırakma konusunda ödeme dâhilinde herhangi bir farmakolojik tedavi başlayamamaktadır. Birinci basamakta çalışan hekimlerimizin gördükleri hasta sayıları dikkate alındığında, hastalarının kolaylıkla ulaşabildikleri birinci basamak hekimlerimizin sigara bırakma amaçlı farmakolojik tedavileri reçeteleyebilmeleri daha çok sigara içene tedavi başlanabilmesini ve daha sıklıkla takibinin yapılabilmesini sağlayacaktır. Aynı şekilde, katılımcılarımızda sigara bırakma polikliniklerinde verilen bu hizmetlerin aile sağlı $\breve{g}_{1}$ merkezleri gibi kolay ulaşabilecekleri ve yakınlarıyla gidebilecekleri merkezlerde yapilabilmesi önerisinde bulunmuşlardır. Hekimlerin, sigara kullanan hastalara sigarayı bırakmalarına yönelik telkin, öneri ve destekleri, onları sigara bırakma konusunda cesaretlendirmektedir. ${ }^{36}$ Sigarayı bırakmayı düşünmeyen kişilere, sigara içmeyi azaltma hedefi sunmanın, bu bireylerin tedavi programına katılımlarını arttırdığ devamını, uzun süreli bakımı teşvik etiği bildirilmiştir. ${ }^{37}$ Birinci basamakta, hekimlerimizin kayıtlı nüfuslarını gerek periyodik muayeneler sırasında gerekse diğer başvurular sırasında görebiliyor olmalarını hastalarının, sigara içme eğilimlerini öğrenebilmeleri ve kişiye yönelik eyleme geçebilmeleri açısından firsat olarak değerlendirebiliriz.

Danimarka'da, görünür ortamlarda sigara içmeyi yasaklayan yasa yürürlükteyken öğrenciler üzerinde yapılan bir çalışmada, öğrencilerin öğretmenlerini okul dişında sigara içerken gördüğü ve bu durumun annenin, babanın ve en iyi arkadaşın sigara içimi ile birlikte sigara içmeyi etkileyen bir faktör olduğu bildirilmiştir. ${ }^{38,39} \mathrm{Bu}$ durum, öğretmenlerin bu konuda yeterli bilgisi olmadığını ya da okul idaresinin bu konuda hassas davranmadığını düşündürmektedir. Sigara kullanımını önleme konusunda, okullarda, özellikle yatılı okullarda ailenin yerini tutan öğretmen ve okul personeli önemli bir rol oynamaktadır. Çalışmamızda, erken dönemde özellikle okullarda eğitimlerin verilmesi gerektiği diğer önerilerdendir. Yapılan çalışmalarda, özellikle annesi sigara içenlerde sigara içme sıklığı daha fazla olduğu görülmektedir. ${ }^{19}$ Katılımcılarımızda özellikle anne eğitimlerine destek önerisinde bulunmuştur. Çalışmamızdaki önerilerin büyük kısmı aslında "Ulusal Tütün Kontrol Programı Eylem Planı" içerisinde bulunmaktadır. Katılımcılarımız muhtemelen uygulamada eksik olduğunu hissettikleri ve tam olarak uygulandığını anlayamadıkları için öneri olarak belirtmişlerdir. Sağlık çalışanı, eğitimcisi, hangi meslek grubunda olursak olalım Ulusal Tütün Kontrol Programı Eylem Planı' nın uygulanabilmesi ve bunun hizmet verdiğimiz insanlar tarafından hissedilebilmesi istekliliği ile çalışmamız gerekmektedir.

\section{Çalışmanın Kısıtlılıkları:}

Çalışmamız, Bolu merkezde tek bir ASM'ye kayıtlı bireyleri kapsamaktadır. Dolayısıyla bölgemizdeki nüfusu temsil edememektedir. Bunun yanında, katılımcılarda farklı tütün mamullerinin kullanımı sorgulanmamıştır. Ülkemizde artan sigara fiyatlarına karşılık, filtreli sigara kullanan bireylerin yanında, sarma sigara kullanan bireylerin sayısında bir artış ta söz konusu olabileceği düşünülmektedir. Birinci basamakta tütün ve tütün ürünleri kullanımı konusunda yapılacak daha geniş katılımlı ve katılımcıların görüşlerine daha çok yer verebilecek çalışmalara ihtiyaç olduğunu düşünmektedir.

\section{SONUC}

Bölgemizde sigara kullanımı oldukça sık görülmektedir. Geçmişte, içilen ortamda bulunanlarda ve yaşanılan ortamda aktif sigara içen kişilerin olması durumunda sigara içme oranları artmaktadır. Önerilerin çok büyük bölümü aslında mevcut kanunlarımızın içinde bulunmakta ve geniş kitlelerin uygulaması yönünde çalışılmaktadır. Bu mevcut sonuçlarla; aile hekimleri olarak aileye ve yakın çevresine tütün ve tütün ürünleri hakkındaki mevcut kanunlar, sigaraya başlamama ve başlanmışsa bırakma konusunda verilecek destek ve takiple, kişilerin mevcut işleyiş hakkındaki farkındalıklarının artırılması sağlanarak, hem kendilerinde, hem çevrelerinde olumlu etkiler oluşturulmasında yardımcı olabileceğimiz düşünülmektedir ${ }^{3}$

\section{KAYNAKLAR}

1. Altıntaş H, Bozdağ G, Polat C, Salor Ö, Yaman İ, Uğurlu E. Bir kamu kuruluşu bilgi işlem merkezi çalışanlarının sigara içme ile ilgili tutum ve davranışları. Bağımlılık Dergisi 2006; 7(1): 3-10.

2. Global Health Observatory data. Prevalence of tobacco smoking. Available from: http://www.who.int/gho/tobacco/use/en/ Accessed May 20, 2018.

3. Küresel Yetişkin Tütün Kullanımı İstatistikleri Available from: http://www.tuik.gov.tr/PreTablo.do?alt_id=104 2 Accessed May 8, 2018.

4. Hackshaw A, Morris JK, Boniface S, Tang JL, Milenković D. Low cigarette consumption and risk of coronary heart disease and stroke: metaanalysis of 141 cohort studies in 55 study reports. BMJ. 2018;360:j5855.

5. WHO, T.C. Sağlık Bakanlığı, “Türkiye'ye Etkili Tütün Kontrol Politikalarının Uygulanması Üzerine Ortak Ulusal Kapasite Değerlendirmesi" Şubat 2009.

6. World Health Organization. The European Tobacco Control Report 2007. Denmark: World 
Health Organization Regional Office for Europe. Available from: http://www.euro.who.int/Document/E89842.pd fAccessed May 20,2018.

7. Bilir N. Türkiye'de Tütün Kontrolünün Öyküsü. 1. Bask1.Ankara: Ankara Ofset; 2017.s.30-39.

8. Tütün ürünlerinin zararlarının önlenmesi ve kontrolü hakkında kanun. Available from: http://www.mevzuat.gov.tr/MevzuatMetin/1.5. 4207.pdf Accessed May 8, 2018.

9. T.C. Sağlık Bakanlığı. Ulusal tütün kontrol programı ve eylem planı 2008-2012. Ankara, 2008.

10. Van der Wilk EA, Jansen J. Life style related risks: are trends in Europe converging? Public Health 2005; 119(1):55-66.

11. TÜİK. Küresel Yetişkin Tütün Araştırması. Ankara; 2008

12. Bakırcı N, Okuşluk T. İstanbul'da bir grup işyerinde sigara içme yasakları ve bu yasakların çalışanların sigara içme durumlarına etkisi. Toplum Hekimliği Bülteni 2007; 16(1): 19-24.

13. Bozdemir N, Kurdak H. Aile hekimliği disiplin ilkeleri açışından nikotin bağımlılığına yaklaşım. Turkiye Klinikleri J Fam MedSpecial Topics 2016;7(5):35-38.

14. Mevsim V, Dontlu Ç, Yeniçeri N, Özçakar N, Güldal D. Birinci basamak sağlık hizmeti çalışanları sigara ve kanser riski konusunda ne biliyor ve ne yapıyor?. Bağımlılık Dergisi 2005; 6: 65-75.

15. Doğanay S, Sözmen K, Kalaça S, Ünal B. Türkiye'de toplumda sigara içme sıklığı nasıl değişiyor?. Türkiye Halk Sağlığı Dergisi 2012;10(2):93-115.

16. Uysal MA, Kadakal F, Karsidag C, Bayram NG, Uysal O, Yilmaz V. Fagerstrom test for nicotine dependence: reliability in a Turkish sample and factor analysis. Tuberk Toraks. 2004;52(2):115-21.

17. Sigara alışkanlıkları ve sigara ile mücadele kampanyası kamuoyu araştırması raporu (Report of the public poll of smoking habits and antismoking campaign). PIAR 1988.

18. T.C. Sağlık Bakanlığı, Refik Saydam Hıfzıssıhha Merkez Başkanlığı Hıfzıssıhha Mektebi Müdürlüğü. Türkiye Ulusal Hastalık Yükü ve Maliyet Etkililik Çalışması Ulusal Hane Halkı Araştırması 2003. Temel bulgular. Ed: Ünüvar N, Mollahaliloğlu S, Yardım N, Başara B. Ankara: T.C. Sağlık Bakanlığı; 2006

19. Şengezer T, Sivri F, Dilbaz N, Sunay D. Ankara ili Yenimahalle ilçesinde birinci basamak sağlık kuruluşuna başvuran bireylerde tütün bağımlılı̆̆1 ve ilişkili risk faktörleri. Türk Aile Hek Derg 2014;18(1):42-48.

20. Kosku N, Kosku M, Çıkrıkçıoğlu U, Tümer ZÖ. Toraks Derneği üyelerinin sigara konusunda bilgi, tutum ve davranışları. Toraks Dergisi 2003;4(3):223-230.
21. WHO Report on the global tobacco epidemic, 2013: enforcing bans on tobacco advertising, promotion and sponsorship. Available from: http://www.who.int/tobacco/global_report/201 3/en/Accessed May 8, 2018.

22. Nguyen KH, Gomez Y, Homa DM, King BA. Tobaccouse, second hand smoke, and smokefree home rules in multiunit housing. Am J Prev Med 2016; 51(5): 682-692.

23. Berg CJ, Haardörfer R, Windle M, Solomon M, Kegler MC. Smoke-Free Policies in multiunit housing: Smoking behavior and reactions to messaging strategies in supportor in opposition. Prev Chronic Dis. 2015; 12: E98.

24. Baykan Z, Naçar M. Tıp fakültesi öğrencilerinin sigara kullanımı ve tütün kanununa ilişkin görüşleri. Dicle Tıp Dergisi2014; 41 (3): 483 490.

25. Kutlu R, Çivi S. Seydişehir Meslek Yüksekokulu öğrencilerinde sigara kullanma durumu ve etkileyen faktörler. Bağımlılık Dergisi 2006; 7(2): 71-79.

26. Nehir S, Demet MM, Dinç G. Manisa ili kent merkezinde görevli hemşirelerin sigara kullanma düzeyleri ve ilişkili risk etmenleri. Bağımlılık Dergisi 2007; 8(1): 3-10.

27. Uğur A, Akdemir E, Gürsel E. Sigara ve alkol üzerindeki dolaylı vergilerin sağlık harcamaları üzerindeki etkisi. Ekonomi Bilimleri Dergisi 2010;2(1):ISSN: 1309-8020 (Online)

28. Önsüz MF, Topuzoğlu A, Alper Algan A, Soydemir E, Aslan İ.Sigara içen hastaların sigara paketlerinin üzerindeki uyarı yazıları hakkındaki görüşlerinin ve nikotin bağımlılık derecelerinin değerlendirilmesi. Marmara Medical Journal 2009;22(2);111-122.

29. Noar SM. A 10-Year retrospective of research in health mass media campaigns: Where do we go from here? Journal of Health Communicaiton 2006 11(1): 21-42.

30. Townsend J. Price and consumption of tobacco. Br Med Bull 1996; 52(1): 132-142.

31. Peretti-Watel P, Constance J. "It's all we got left". Why poor smokers are less sensitive to cigarette price increases. Int $\mathrm{J}$ Environ Res Public Health 2009;6(2):608-21.

32. Haustein KO. Smoking and poverty. Eur J Cardiovasc Prev Rehabil 2006;13(3):312-318.

33. Topçu S, Akın E, Ulukol B, Orhon FŞ, Başkan S. Sigaranın çocuğa etkileri konusunda ailelerin farkındalıkları, tutum ve davranışları TJFMPC 2018;12(1):35-42

34. TÜİK.Küresel Yetişkin Tütün Araştırması Türkiye 2012. Available from: http://www.halksagligiens.hacettepe.edu.tr/KY TA_TR.pdf Accessed Aug 14, 2018.

35. Karlıkaya C, Öztuna F, Solak ZA, Özkan M, Örsel O. Tütün kontrolü. Toraks Dergisi 2006; 7(1): 51-64. 
36. Schwartz JL: Methods of smoking cessation. Med Clin North Am, 1992; 76:451-76

37. Kotz D. Implementation of a new 'opt-out' default for tobacco treatment is urgentlyneeded, but requires free Access to evidencebasedtreatments. Society for the Study of Addiction. 2015; 110: 387-91

38. Poulsen LH, Osler M, Roberts C, Due P, Damsgaard MT, Holstein BE. Exposure to teachers smoking and adolescent smoking behaviour: analysis of cross sectional data from Denmark. Tob Control 2002;11(3):246-251.

39. Keskinoğlu P, Karakuş N, Pıçakçıefe M, Giray $\mathrm{H}$, Bilgiç $\mathrm{N}$, Kılıç $\mathrm{B}$. İzmir'de Lise öğrencilerinde Sigara İçme Sıklığı ve İçicilik Davranışı Üzerine Sosyal Öğrenmenin Etkisi. Tur Toraks Der 2006;7(3):190-195. 